\title{
SINKRONISASI PERATURAN DAERAH KABUPATEN KUDUS TENTANG PENGEMISAN
}

\author{
Nabila Luthvita Rahma \\ Institut Agama Islam Negeri Kudus \\ Email:nabilalr@iainkudus.ac.id
}

\begin{abstract}
Begging is a disease of society, in legal products in Indonesia so far have two contradictory definitions. One side is the impact of poverty and the other side is considered a community disease. The existence of this difference needs to be analyzed by synchronizing the law. Kudus Regency Regulation (Peraturan Daerah) No. 15 of 2017 is a legal product that aimed to prevent begging in Kudus Regency. The synchronization results show that the content of the Regulation is in line with the Constitution. But in the synchronization process, there are still some problems. That is because the meaning of the act of begging is still considered a community disease, and as an impact of poverty on the other side.
\end{abstract}

Keywords: Begging, Synchronization of Law, Regulatory Legislation.

\begin{abstract}
Abstrak
Pengemisan merupakan penyakit masyarakat, dalam produk hukum di Indonesia selama ini mmemiliki dua definisi yang kontradiktif. Satu sisi sebagai dampak kemiskinan dan sisi lain dianggap sebagai penyakit masyarakat. Adanya perbedaan ini perlu dianalisa dengan sinkronisasi hukum. Terbitnya Perda Kabupaten Kudus Nomor 15 tahun 2017 merupakan produk hukum yang ditujukan untuk menanggulangi pengemisan di Kabupaten Kudus. Hasil sinkronisasi menunjukkan jika materi muatan dalam Perda tersebut sudah sejalan dengan Konstitusi. Namun dalam proses sinkronisasi tersebut, masih terdapat beberapa kendala. Hal tersebut dikarenakan pemaknaan tindakan pengemisan yang masih dianggap sebagai penyakit masyarakat, dan sebagai dampak kemiskinan pada sisi yang lain.
\end{abstract}

Kata Kunci : Pengemisan, Sinkronisasi Hukum, Peratuan Perundang-Undangan 


\section{PENDAHULUAN}

Pasal 28 H Undang-Undang Dasar Negara Republik Indonesia Tahun 1945 disebutkan bahwa setiap orang berhak hidup sejahtera lahir dan batin, bertempat tinggal, dan mendapatkan lingkungan hidup baik dan sehat serta berhak memperoleh pelayanan kesehatan. Pasal $28 \mathrm{H}$ tersebut menyiratkan bahwa kesejahteraan merupakan hak warga negara, dan penyelenggara negara berkewajiban mewujudkannya. Perlindungan sosial bagi warga negara ditegaskan kembali dalam Pasal 34 ayat (1) UUD NRI Tahun 1945. Disebutkan bahwa fakir miskin dan anak terlantar dipelihara oleh negara.

Pemenuhan kesejahteraaan masyrakat sebagai bentuk hak manusia, diamanatkan lebih lanjut dalam Undang-Undang Kesejahteraan Sosial yakni Undang-Undang Nomor 11 Tahun 2009. Negara kesejahteraan sejatinya adalah strategi pembangunan kesejahteraan sosial yang memberi peran lebih besar kepada negara dalam penyelenggaraan sistem jaminan sosial secara terencana, melembaga, dan berkesinambungan.Bentuk perlindungan negara mencakup jaminan sosial dasar yang melindungi warga negara dari risiko kehilangan pendapatan karena sakit, kematian, menganggur, kecelakaan kerja dan kehamilan (Soendoro, 2009: 36).

Dampak yang kerap terjadi dari tingkat kemiskinan yang tinggi adalah tindak pengemisan.Tindakan pengemisan, pada dasarnya merupakan fenomena sosial yang berkaitan erat dengan masyarakat.Pengemisan secara umum didefinisikan sebagai tindakan mengemis (meminta-minta). Pengemis adalah orang-orang yang mendapatkan penghasilan dengan meminta-minta di muka umum dengan pelbagai cara dan alasan untuk mengharapkan belas kasihan dari orang lain. (http://gedesedana.wordpress.com/2009/07/28/faktorpenyebab-terjadinya-gelandangan-dan-pengemis/, diakses pada tanggal 31 Juni 2019).

Pengemisan yang menjadi fenomena sosial dapat terkategorikan sebagai penyakit masyarakat. Menurut Serjono Soekanto, pada prinsipnya penyakit masyarakat timbul akibat terjadinya persinggungan dengan norma-norma yang hidup di tengah masyarakat. (Soekanto, 2006 : 24). Penyakit sosial kerap bersinggungan dengan permasalahan terhadap hak asasi manusia (HAM). Jika dikaji lebih subyektif, tindak pengemisan yang sering diidentikkan dengan penyakit sosial juga bersinggungan dengan Pasal 34 (1) UUD NRI Tahun 1945 yang mengamanatkan negara untuk bertanggung jawab memelihara fakir miskin dan anak terlantar. 
Tabel 1

Hasil Penindakan Penyakit Masyarakat oleh Satuan Sabhara

\begin{tabular}{|l|c|c|c|c|}
\hline Item & 2014 & 2015 & 2016 & 2017 \\
\hline Pengemis & 21 & 19 & 19 & 3 \\
\hline Pengamen & 23 & 84 & 67 & 49 \\
\hline Gelandangan & - & - & 16 & - \\
\hline
\end{tabular}

Sumber : Satuan Sabhara Polres Kudus (data/07 Agustus 2017)

Tindakan pengemisan merupakan salah satu materi yang diatur didalam Peraturan Daerah Kabupaten Kudus Nomer 10 Tahun 1996 tentang Kebersihan, Ketertiban, dan Keindahan (K3) yang diubah dengan Peraturan Daerah Kabupaten Kudus Nomor 8 Tahun 2015 yang selanjutnya akan disebut sebagai Perda tentang K3. Perda K3 tersebut menyebutkan jika ketentuan pidana dalam hal pelanggaran perda tersebut ialah kurungan selama-lamanya tiga bulan atau denda setinggi-tingginya Rp.50.000.000,-.

Berdasarkan fenomena pengemisan seperti yang tersebut di atas di Kabupaten Kudus, ada beberapa hal yang perlu dikaji lebih dalam, diantaranya konstruksi pengemisan dan cara menangani pengemisan tersebut. Pengemisan yang pada mulanya merupakan dampak dari kemiskinan atau rendahnya kesejahteraan, dewasa ini mulai bergeser menjadi penyakit masyarakat yang terasa mengganggu ketertiban umum. Adanya sinkronisasi hukum diperlukan untuk melihat pengemisan dari berbagai Peraturan Perundang-Undangan terkait. Mulai dari UndangUndang Dasar Negara Republik Indonesia Tahun 1945 hingga Peraturan Daerah Kabupaten Kudus Nomor 15 Tahun 2017 tentang Penganggulangan Gelandangan, Pengemis,dan Anak Jalanan. Hasil dari sinkronisasi tersebut dapat digunakan sebagai rujukan dalam penyelesaian masalah pengemisan di Kabupaten Kudus.

\section{METODE PENELITIAN}

Penelitian ini menggunakan metode pendekatan yuridis normatif dengan spesifikasi penelitian yaitu deskriptif analistis, sedangkan sumber datanya adalah data sekunder yang berasal dari bahan hukum primer berupa peraturan perundang-undangan, bahan hukum sekunder berasal dari buku-buku, karya tulis ilmiah, serta bahan hukum tersier berupa kamus bahasa Indonesia, kamus hukum. Selanjutnya data dianalisa menggunakan teknik analisa diskriptif kualitatif. 


\section{PEMBAHASAN}

\section{Kontroversi Pemaknaan Pengemisan dalam Konstitusi dan Peraturan Perundang-Undangan}

\section{Pemaknaan Pengemisan Dalam Peraturan Perundang-Undangan}

Adanya pengemisan termasuk dalam penyakit masyarakat ini disebabkan karena pengemisan dianggap sebagai penyimpangan yang merusak tata sosial dari masyarakat. Pengemisan dapat menjadi gejala (indikasi) bahwa kestabilan struktur sosial di dalam masyarakat mulai goyah. Selain itu, pengemisan dianggap sebagai gejala menyimpang yang tidak umum dimata masyarakat yang dianggap tidak sejalan dengan nilai-nilai yang dianut masyarakat dan tujuan bersama. Pengemisan pun identik dengan degradasi moral karena menunjukkan bahwa pelaku sudah tidak malu lagi untuk meminta minta (Direktorat Pelayanan dan Rehabilitasi Sosial Tuna Sosial, "Standar Pelayanan Minimal Pelayanan dan Rehabilitasi Sosial Gelandangan dan Pengemis, 2005).

Gejala pengemisan seringkali dianggap sebagai tindakan yang mengganggu ketertiban umum dan merusak keindahan tatanan sosial dimasyarakat. Oleh sebab hal tersebut, pengemisan dikategorikan sebagai tindak pidana yang termasuk didalam kategori pelanggaran. Adapun pengemisan disebutkan dalam Pasal 504 KUHP dengan ancaman kurungan paling lama 6 (enam) minggu. Kemiskinan dalam konteks sosial dan kehidupan bernegara memang menjadi tanggung jawab pemerintah untuk dapat menyediakan kehidupan yang baik bagi rakyatnya.Adanya kemiskinan terlebih pengemisan menjadi indikator bahwa negara belum mampu memberikan kesejahteraan tersebut sesuai dengan tujuan dalam bernegara. Oleh sebab itu, pengemisan diposisikan menjadi dampak dari sekian keadaan yang mendesak dan menjadi tanggung jawab pemerintah untuk menangani dengan baik.

Disinilah pengemisan memiliki dua definisi yang saling berseberangan. Disatu sisi, dilihat dari segi hukum, dan sisi lain memandang dari sudut sosial. Sisi hukum memandang pengemisan sebagai pelanggaran terhadap ketertiban dan merusak tatanan moral, sedangkan sisi sosiologi memandang pengemisan sebagai perbuatan menyimpang yang salah satu pemicunya adalah kemiskinan.

\section{Kebijakan Pengaturan Pengemisan di Kabupaten Kudus}

Kebijakan pengaturan pengemisan di Kabupaten Kudus, telah tercantum dalam Peraturan Daerah Kabupaten Kudus Nomor 10 Tahun 1996 tentang Kebersihan, Ketertiban, dan Keindahan (selanjutnya disingkat menjadi Perda K3 yang dirubah dengan Perda Nomor 8 Tahun 2015. 
Dalam Pasal 13 huruf (f) dan (g) tentang Ketentuan Larangan Perda K3 disebutkan bahwa :

a. Menggunakan trotoar tepi jalan umum, lapangan-lapangan, kuburan umum untuk tempat tinggal, berjualan atau menyimpan / meletakkan barang dagangan.

b. Menggunakan trotoar atau tepi jalan memarkir kendaraan.

Sedangkan dalam Bab VII A Pasal 14 a tentang ketentuan pidana disebutkan bahwa :

a. Orang pribadi atau Badan yang melanggar ketentuan Pasal 3, Pasal 5 ayat (4), Pasal 6, Pasal 7, Pasal 8, Pasal 12, dan Pasal 13, dikenakan sanksi pidana kurungan paling lama 3 (tiga) bulan atau denda paling banyak Rp 50.000.000,- (lima puluh juta rupiah).

b. Tindak Pidana sebagaimana dimaksud pada ayat (1) adalah pelanggaran.

Ketidakefektifan Perda K3 bisa dilihat dari praktik penegakannya. Satpol PP yang bertugas sebagai penegak Perda, dalam hal melakukan razia terhadap pengemisan dilakukan dengan cara represif. Selain itu, tindak lanjut dari razia tersebut juga kurang dapat menfasilitasi penanggulangan pengemisan. Pengemis yang tertangkap selanjutnya dilakukan pendataan identitas, dan tindakan selanjutnya yaitu pembianaan menjadi tanggung jawab dari Dinas Sosial yang bekerja sama dengan Unit Rehabilitasi Sosial.

Penegakan hukum maupun penanggulangan gelandangan, pengemis, dan Anak Jalanan di Kabupaten Kudus nampaknya belum dapat dikatakan berhasil. Hal ini terlihat dari banyaknya pengemis, gelandangan dan anak jalanan yang memadati tempat-tempat tertentu, seperti traffic light jalan lingkar Kudus-Pati, dan beberapa traffict light dikawasan kota, dan pengemis yang berkeliling dari rumah ke rumah. Bahkan, jumlah mereka dapat bertambah secara signifikan pada saatsaat tertentu seperti memasuki Bulan Ramadhan. Hal lain adalah adanya sebuah perkampungan yang dinamakan Kampung Pengemis karena sebagian besar warganya bermata pencaharian sebagai pengemis, gelandangan dan anak jalanan (Naskah Akademik Rancangan Peraturan Daerah Kabupaten Kudus tentang Pengemis, Gelandangan, dan Orang Terlantar; Baperenda Kabupaten Kudus Tahun 2016).

Menurut Lawrence M Friedman, Berhasil tidaknya penegakan hukum dalam masyarakat, bergantung pada sistem hukum (legal system). Sistem hukum merupakan kumpulan dari semua subsistem. Dalam buku The Legal System, sistem hukum mencermati bagaimana institusi-institusi hukum berelasi dengan masyarakat. Sistem hukum terdiri dari substansi hukum (legal substance), struktur/pranata hukum (legal structure), dan budaya/kultur hukum (legal culture). 
Secara singkat, cara lain untuk menggambarkan ketiga unsur sistem hukum tersebut adalah sebagai berikut : (Friedman, 2009:15)

a. Sruktur diibaratkan sebagai mesin.

b. Substansi adalah apa yang dikerjakan dan dihasilkan oleh mesin tersebut.

c. Kultur hukum adalah apa saja dan siapa saja yang memutuskan untuk menghidupkan dan mematikan mesin itu, serta memutuskan bagaimana mesin itu berkerja dan digunakan.

3. Kebijakan Sinkronisasi Pengaturan Pengemisan Dalam Peraturan Perundang-Undangan

Sinkronisasi Peraturan Perundang-Undangan adalah penyelarasan dan penyerasian berbagai Peraturan PerundangUndangan yang terkait dengan Peraturan Perundang-Undangan yang telah ada dan yang sedang disusun yang mengatur suatu bidang tertentu.

\section{Sinkronisasi Horisontal Pengaturan Pengemisan di Indonesia}

Adapun tabel sinkronisasi horisontal tentang pengemisan menurut peraturan perundang-undangan di Indonesia adalah sebagai berikut:

\section{Tabel 1}

Sinkronisasi Horisontal

Pemaknaan Pengemisan dalam Peraturan Perundang-Undangan

\begin{tabular}{|c|c|c|}
\hline \multirow{2}{*}{$\begin{array}{l}\text { Peraturan Perundang- } \\
\text { Undangan }\end{array}$} & \multicolumn{2}{|c|}{ Pemaknaan Pengemisan } \\
\hline & $\begin{array}{c}\text { Penyakit } \\
\text { Masyarakat }\end{array}$ & Dampak Kemiskinan \\
\hline UUD NRI Tahun 1945 & & $\begin{array}{l}\text { Ps } \mathbf{2 8 ~} \mathbf{H} \text { ayat (1) } \\
\text { 1) Setiap orang berhak } \\
\text { hidup sejahtera lahir dan } \\
\text { batin, bertempat tinggal, } \\
\text { dan mendapatkan } \\
\text { lingkungan hidup yang } \\
\text { baik dan sehat serta } \\
\text { berhak memperoleh } \\
\text { pelayanan kesehatan. } \\
\text { Ps } 34 \text { (1) } \\
\text { Fakir miskin dan anak-anak } \\
\text { yang terlantar dipelihara } \\
\text { oleh negara. }\end{array}$ \\
\hline KUHP & $\begin{array}{l}\text { Ps } 504 \text { KUHP } \\
\text { 1) Barang siapa } \\
\text { yang mengemis }\end{array}$ & \\
\hline
\end{tabular}




\begin{tabular}{|c|c|c|}
\hline & $\begin{array}{l}\text { dimuka umum, } \\
\text { diancam karena } \\
\text { melakukan } \\
\text { pengemisan } \\
\text { dengan pidana } \\
\text { kurungan paling } \\
\text { lama enam } \\
\text { minggu; } \\
\text { 2) Pengemisan } \\
\text { yang dilakukan } \\
\text { oleh tiga orang } \\
\text { atau lebih, yang } \\
\text { berumur diatas } \\
\text { enam belas } \\
\text { tahun, diancam } \\
\text { pidana } \\
\text { kurungan paling } \\
\text { lama tiga } \\
\text { bulan,". }\end{array}$ & \\
\hline $\begin{array}{l}\text { PP Nomer } 31 \text { Tahun } \\
1980 \text { tentang } \\
\text { Penanggulangan } \\
\text { Pengemis } \\
\text { Gelandangan }\end{array}$ & $\begin{array}{l}\text { Pasal 1 angka } 4 \\
\text { huruf (b), } \\
\text { Usaha preventif } \\
\text { adalah usaha secara } \\
\text { terorganisir yang } \\
\text { meliputi } \\
\text { penyuluhan, } \\
\text { bimbingan, latihan, } \\
\text { dan pendidikan, } \\
\text { pemberian bantuan, } \\
\text { pengawasan serta } \\
\text { pembinaan lanjut } \\
\text { kepada berbagai } \\
\text { pihak yang ada } \\
\text { hubungannya } \\
\text { dengan pandan } \\
\text { pergelandangan } \\
\text { dan pengemisan, } \\
\text { sehingga akan } \\
\text { tercegah terjadinya: } \\
\text { b. meluasnya a dan } \\
\text { pengaruh akibat adanya } \\
\text { pergelandangan }\end{array}$ & 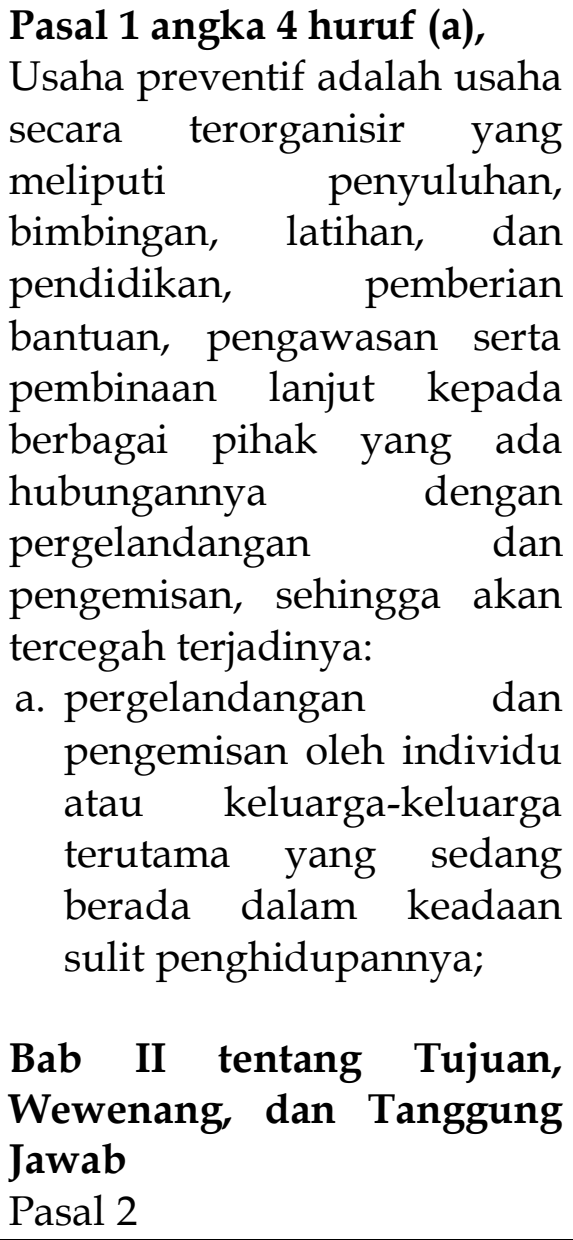 \\
\hline
\end{tabular}




\begin{tabular}{|c|c|c|}
\hline & $\begin{array}{l}\text { dan pengemisan } \\
\text { di dalam } \\
\text { masyarakat yang } \\
\text { dapat } \\
\text { mengganggu } \\
\text { ketertiban dan } \\
\text { kesejahteraan } \\
\text { pada umumnya; } \\
\text { Pasal 1 angka 2 } \\
\text { Pengemis adalah } \\
\text { orang-orang yang } \\
\text { mendapatkan } \\
\text { penghasilan dengan } \\
\text { meminta-minta di } \\
\text { muka umum } \\
\text { dengan berbagai } \\
\text { cara dan alasan } \\
\text { untuk dar } \\
\text { mengharapkan } \\
\text { belas kasihan dari } \\
\text { orang lain }\end{array}$ & 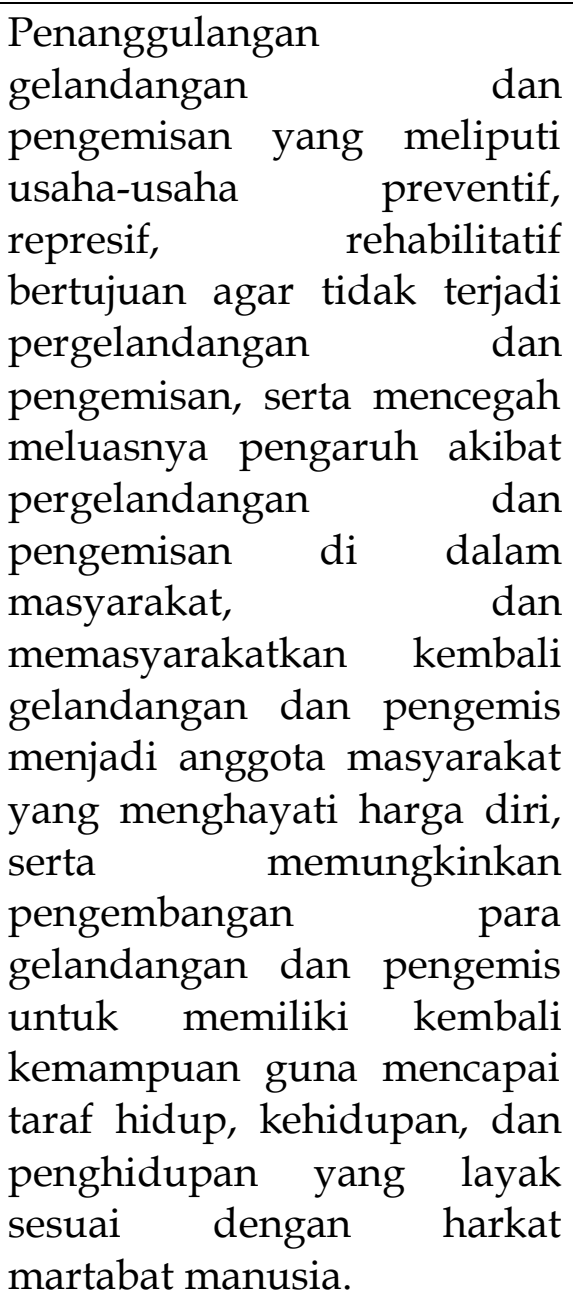 \\
\hline $\begin{array}{l}\text { Undang-Undang } \\
\text { Nomor } 39 \text { Tahun } 1999 \\
\text { tentang Hak Asasi } \\
\text { Manusia }\end{array}$ & & $\begin{array}{l}\text { Bab III } \\
\text { Bagian } 1 \text { Pasal } 9 \\
\text { 1) Setiap orang berhak } \\
\text { untuk hidup, } \\
\text { mempertahankan hidup } \\
\text { dan meningkatkan taraf } \\
\text { kehidupannya. } \\
\text { 2) Setiap orang berhak hidup } \\
\text { tenteram, aman, damai, } \\
\text { bahagia, sejahtera lahir } \\
\text { dan batin. } \\
\text { 3) Setiap orang berhak atas } \\
\text { lingkungan hidup yang } \\
\text { baik dan sehat. } \\
\text { Bagian } 7 \text { Pasal } 36 \\
\text { 1) Setiap orang berhak }\end{array}$ \\
\hline
\end{tabular}




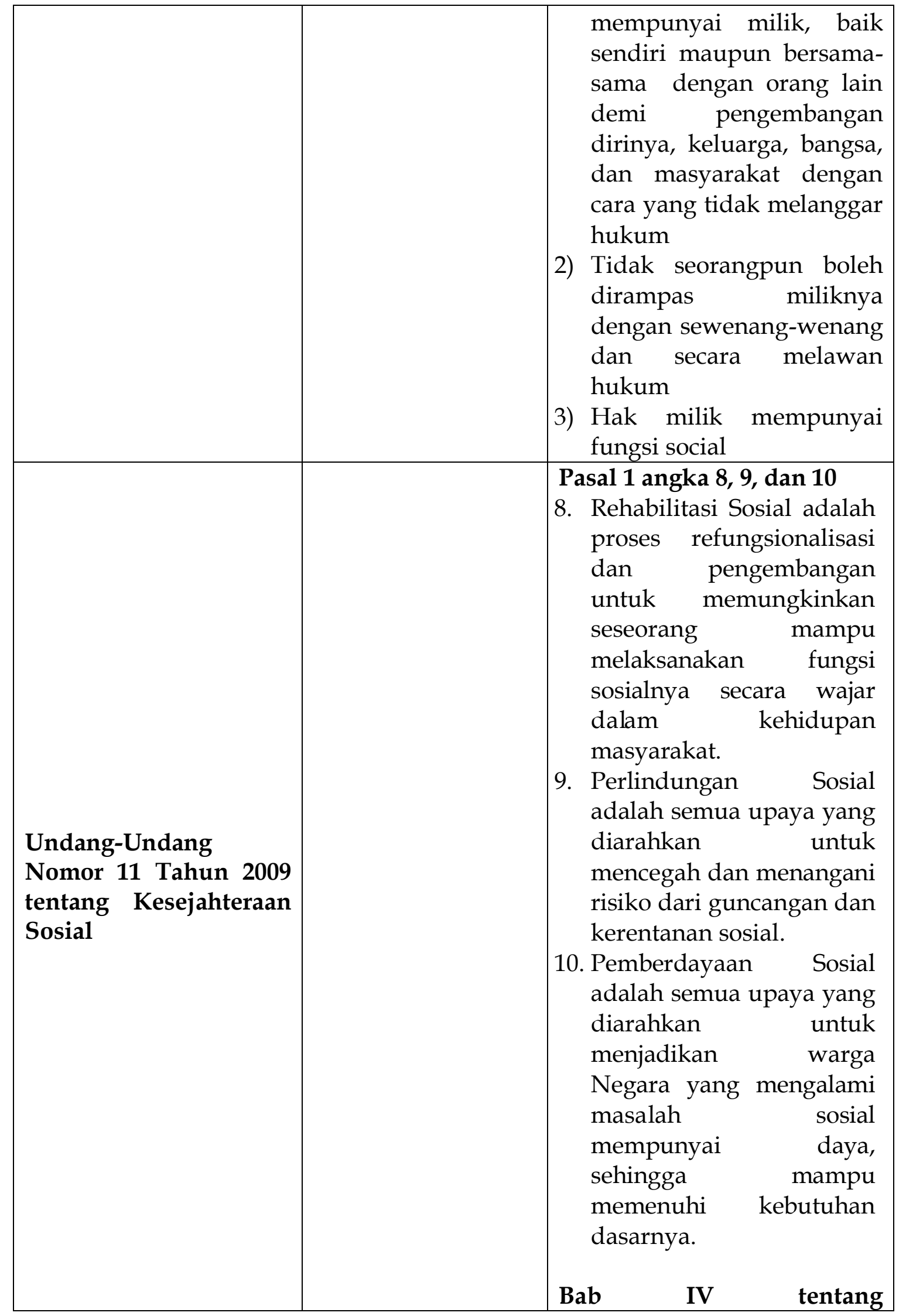




\begin{tabular}{|c|c|c|}
\hline & & $\begin{array}{l}\text { Penanggulangan } \\
\text { Kemiskinan } \\
\text { Pasal 19 } \\
\text { Penanggulangan } \\
\text { kemiskinan merupakan } \\
\text { kebijakan, program, dan } \\
\text { kegiatan yang dilakukan } \\
\text { terhadap orang, keluarga, } \\
\text { kelompok dan/atau } \\
\text { masyarakat yang tidak } \\
\text { mempunyai sumber } \\
\text { ataumempunyai tidak } \\
\text { mata pencahariandan tal } \\
\text { dapat memenuhi } \\
\text { kebutuhanyanglayakbagike } \\
\text { manusiaan. }\end{array}$ \\
\hline $\begin{array}{l}\text { Perda No. } 8 \text { Tahun } \\
2015 \text { tentang Perubaha } \\
\text { Atas Perda No } 10 \text { Th } \\
1996 \\
\text { Kebersihan, } \\
\text { Keindahan, } \\
\text { Ketertiban } \\
\text { (K3) }\end{array}$ & $\begin{array}{l}\text { Pasal } 14 \text { huruf (f) } \\
\text { dan (g) } \\
\text { f. Menggunakan } \\
\text { trotoar tepi jalan } \\
\text { umum, } \\
\text { lapangan- } \\
\text { lapangan, } \\
\text { kuburan umum } \\
\text { untuk tempat } \\
\text { tinggal, berjualan } \\
\text { atau menyimpan } \\
\text { /meletakkan } \\
\text { barang } \\
\text { dagangan. } \\
\text { g. Menggunakan } \\
\text { trotoar atau tepi } \\
\text { jalan memarkir } \\
\text { kendaraan. }\end{array}$ & \\
\hline $\begin{array}{l}\text { Perda No. } 15 \text { Tahun } \\
2017 \text { tentang } \\
\text { Penanggulangan } \\
\text { Gelandangan, } \\
\text { Pengemis dan Anak } \\
\text { Jalanan }\end{array}$ & & $\begin{array}{l}\text { Bab II tentang Asas dan } \\
\text { Tjuan } \\
\text { Pasal } 3 \\
\text { Penanganan Gelandangan } \\
\text { Pengemis dan Anak Jalanan } \\
\text { bertujuan untuk: } \\
\text { a. Mencegah dan } \\
\quad \text { mengantisipasi }\end{array}$ \\
\hline
\end{tabular}




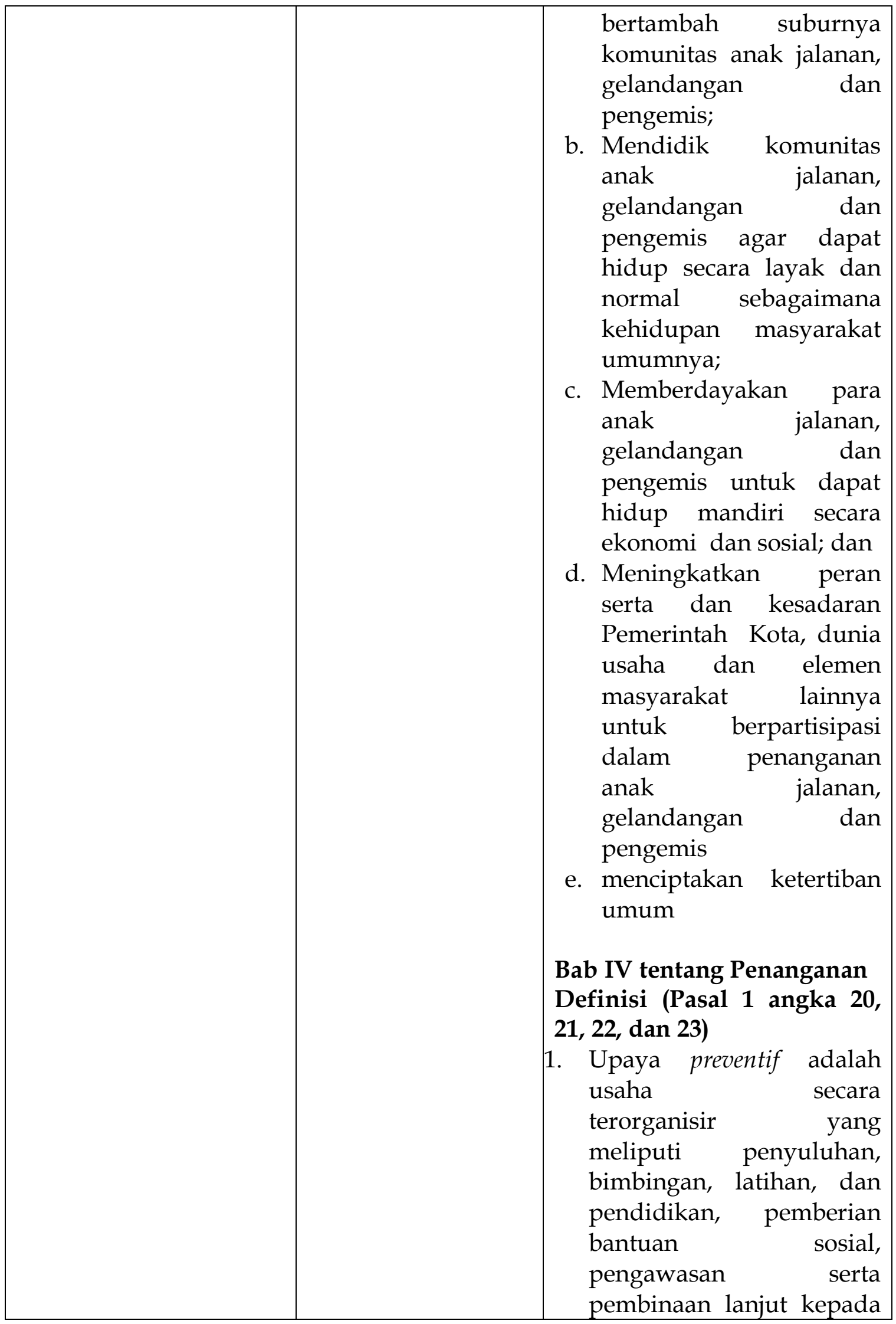




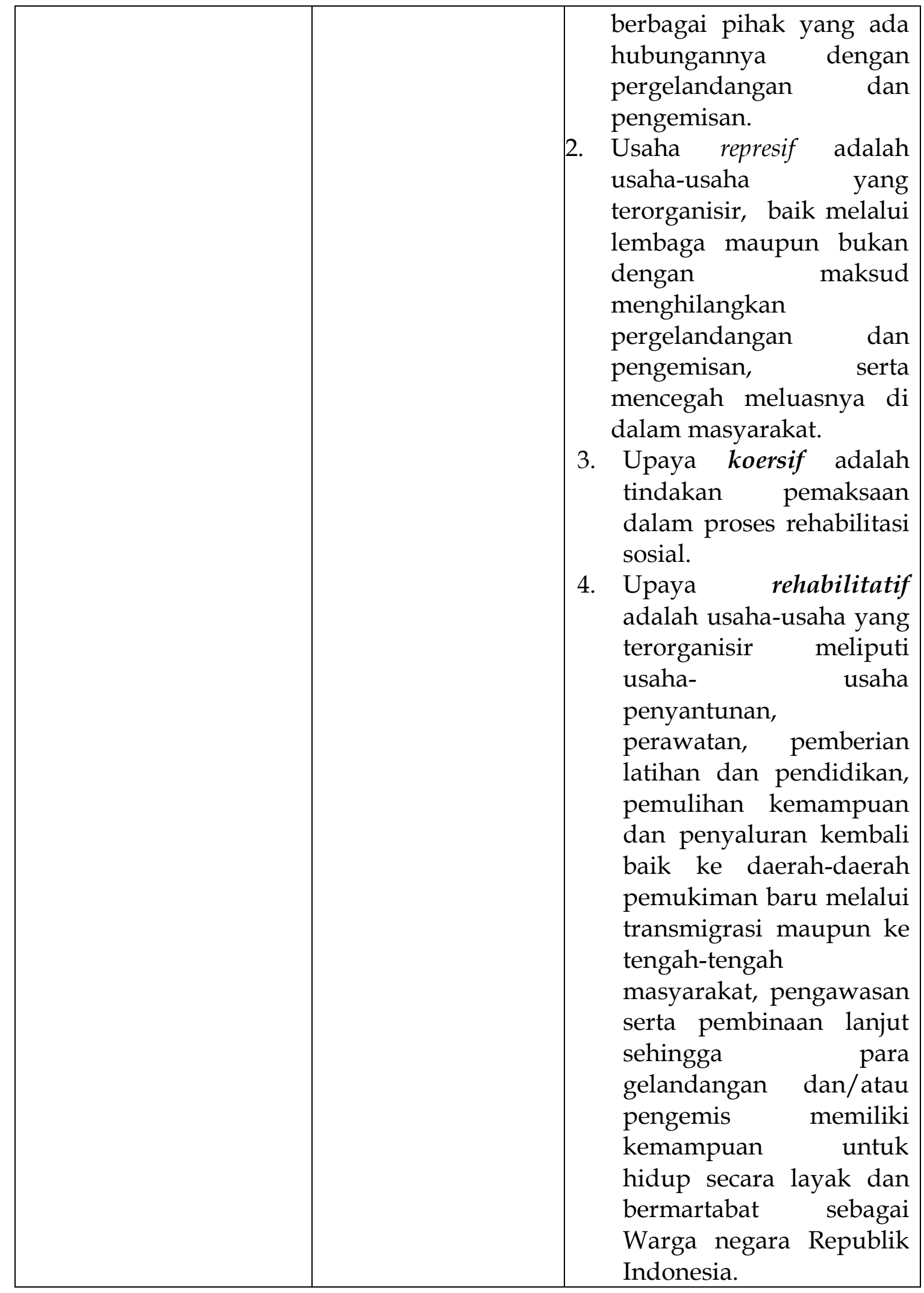


Tabel 2

Sinkronisasi Horisontal

Penegakan Hukum Pengemisan dalam Peraturan Perundang-Undangan

\begin{tabular}{|c|c|c|}
\hline \multirow[b]{2}{*}{$\begin{array}{c}\text { Peraturan Perundang- } \\
\text { Undangan }\end{array}$} & \multicolumn{2}{|c|}{ Penegakan Hukum } \\
\hline & $\begin{array}{c}\text { Aparat Penegak } \\
\text { Hukum }\end{array}$ & Satpol PP \\
\hline UUD NRI Tahun 1945 & & \\
\hline KUHP & Idem dengan tabel 1 & \\
\hline $\begin{array}{l}\text { PP Nomor } 31 \text { Tahun } \\
1980 \text { tentang } \\
\text { Penanggulangan } \\
\text { Pengemis } \\
\text { Gelandangan }\end{array}$ & & 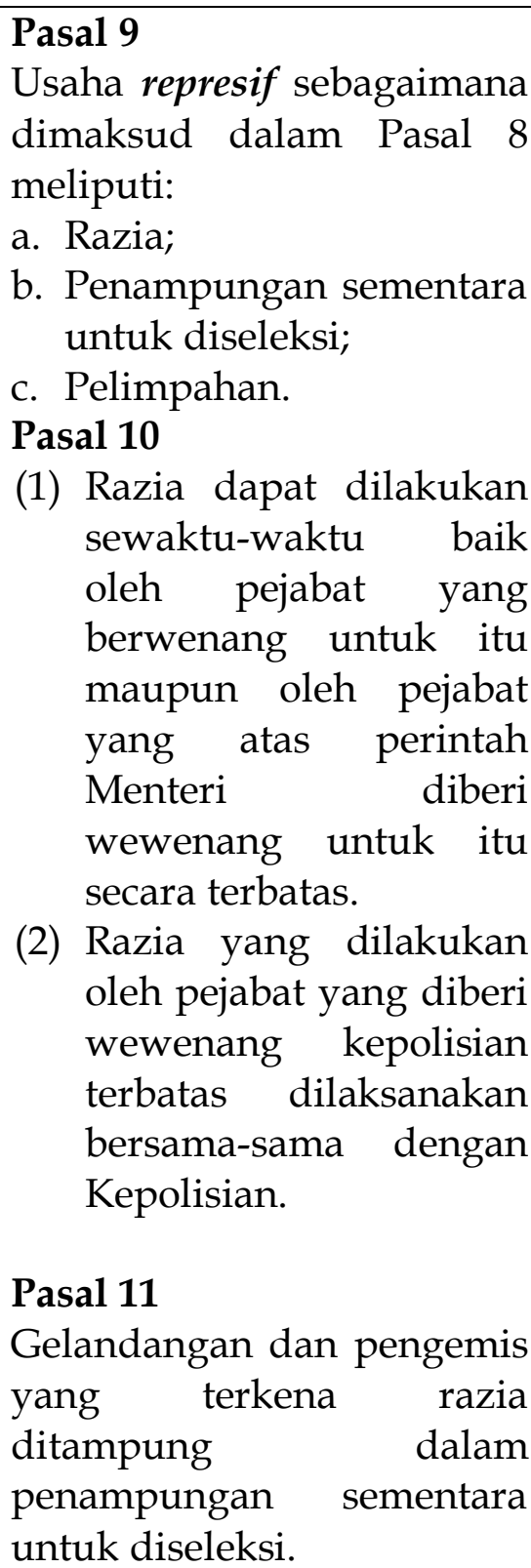 \\
\hline $\begin{array}{l}\text { UU Nomor } 39 \text { Tahun } \\
1999 \text { tentang Hak Asasi } \\
\text { Manusia }\end{array}$ & $\begin{array}{lr}\text { Bab V } & \\
\text { Kewajiban } & \text { dan } \\
\text { Tanggung } & \text { Jawab }\end{array}$ & \\
\hline
\end{tabular}




\begin{tabular}{|c|c|c|}
\hline & $\begin{array}{l}\text { Pemerintah } \\
\text { Pasal 71 } \\
\text { Pemerintah wajib dan } \\
\text { bertanggung jawab } \\
\text { menghormati, } \\
\text { melindungi, } \\
\text { menegakan, dan } \\
\text { memajukan hak asasi } \\
\text { manusia yang diatur } \\
\text { dalam Undang- } \\
\text { undang ini, peraturan } \\
\text { perundang-undangan } \\
\text { lain, dan hukum } \\
\text { internasional tentang } \\
\text { hak asasi manusia } \\
\text { yang.diterima oleh } \\
\text { negara Republik } \\
\text { Indonesia. }\end{array}$ & \\
\hline $\begin{array}{l}\text { UU Nomer } 11 \text { Tahun } \\
2009 \\
\text { Kesejahteraan Sosial }\end{array}$ & $\begin{array}{l}\text { Bab X Pembinaan dan } \\
\text { Pengawasan Serta } \\
\text { Pemantauan dan } \\
\text { Evaluasi } \\
\text { Pasal 54 } \\
\text { (1) Pemerintah dan } \\
\text { pemerintah } \\
\text { daerah } \\
\text { melakukan } \\
\text { pembinaan dan } \\
\text { pengawasan } \\
\text { terhadap } \\
\text { aktivitas pelaku } \\
\text { penyelenggaraan } \\
\text { kesejahteraan } \\
\text { social sesuai } \\
\text { dengan } \\
\text { kewenangannya } \\
\text { masing-masing. } \\
\text { (2) Masyarakat dapat } \\
\text { melakukan } \\
\text { pembinaan dan } \\
\text { pengawasan } \\
\text { terhadap } \\
\text { aktivitaspelaku }\end{array}$ & \\
\hline
\end{tabular}




\begin{tabular}{|c|c|c|}
\hline & $\begin{array}{l}\text { penyelenggaraan } \\
\text { kesejahteraan } \\
\text { sosial. }\end{array}$ & \\
\hline $\begin{array}{l}\text { Perda No } 08 \text { Tahun } \\
2015 \text { Tentang Perubaha } \\
\text { Atas Perda No } 10 \text { Th } \\
1996 \\
\text { Kebersihan, } \\
\text { Keindahan, } \\
\text { Ketertiban } \\
\text { K3) }\end{array}$ & & $\begin{array}{l}\text { Bab VII A Pasal 14 a } \\
\text { 1) Orang pribadi atau } \\
\text { Badan yang melanggar } \\
\text { ketentuan Pasal 3, Pasal } \\
5 \text { ayat (4), Pasal 6, Pasal } \\
\text { 7, Pasal 8, Pasal 12, dan } \\
\text { Pasal 13, dikenakan } \\
\text { sanksi pidana } \\
\text { kurungan paling lama } 3 \\
\text { (tiga) bulan atau denda } \\
\text { paling banyak Rp } \\
\text { 50.000.000,00 (lima } \\
\text { puluh juta rupiah). } \\
\text { Tindak Pidana } \\
\text { sebagaimana dimaksud } \\
\text { pada ayat (1) adalah } \\
\text { pelanggaran. }\end{array}$ \\
\hline $\begin{array}{l}\text { Perda No } 15 \text { Tahun } \\
2017 \text { tentang } \\
\text { Penanggulangan } \\
\text { Gelandangan, } \\
\begin{array}{l}\text { Pengemis dan Anak } \\
\text { Jalanan }\end{array}\end{array}$ & & $\begin{array}{l}\text { Bab X Pasal } 21 \\
\text { Pasal } \mathbf{2 1} \\
\text { 1. Setiap orang yang } \\
\text { melanggar ketentuan } \\
\text { Pasal } 19 \text { huruf a, } \\
\text { diancam } \\
\text { denganhukuman } \\
\text { pidana kurungan } \\
\text { paling lama } 6 \text { (enam) } \\
\text { minggu dan/atau } \\
\text { denda paling banyak } \\
\text { Rp 10.000.000,00 } \\
\text { (sepuluh juta rupiah). } \\
\text { (melakukan } \\
\text { Pergelandangan } \\
\text { dan/atau Pengemisan } \\
\text { baik perorangan atau } \\
\text { berkelompok dengan } \\
\text { alasan, cara dan alat } \\
\text { apapun untuk } \\
\text { menimbulkan belas } \\
\text { kasihan orang lain; Ps. }\end{array}$ \\
\hline
\end{tabular}




\section{9 huruf a)}

2. Setiap orang yang melanggar ketentuan Pasal 19 huruf b diancam dengan hukuman pidana kurungan paling lama 2 (dua) bulan dan/atau denda paling banyak Rp 20.000.000,00 (dua puluh juta rupiah). (memperalat orang lain dengan mendatangkan seseorang/beberapa orang baik dari dalam daerah ataupun dari luar daerah untuk maksud melakukan pergelandangan dan/atau pengemisan; dan anak jalanan. Ps. 19 huruf b)

3. Setiap orang yang melanggar ketentuan Pasal 19 huruf c diancam dengan hukuman pidana kurungan paling lama 3 (tiga) bulan dan/atau denda paling banyak Rp 50.000.000,00 (limapuluh juta rupiah) sebagaimana diatur dalam Kitab UndangUndang Hukum Pidana. (mengajak, membujuk, membantu, menyuruh, memaksa, dan mengkoordinir orang lain secara perorangan atau berkelompok sehingga 


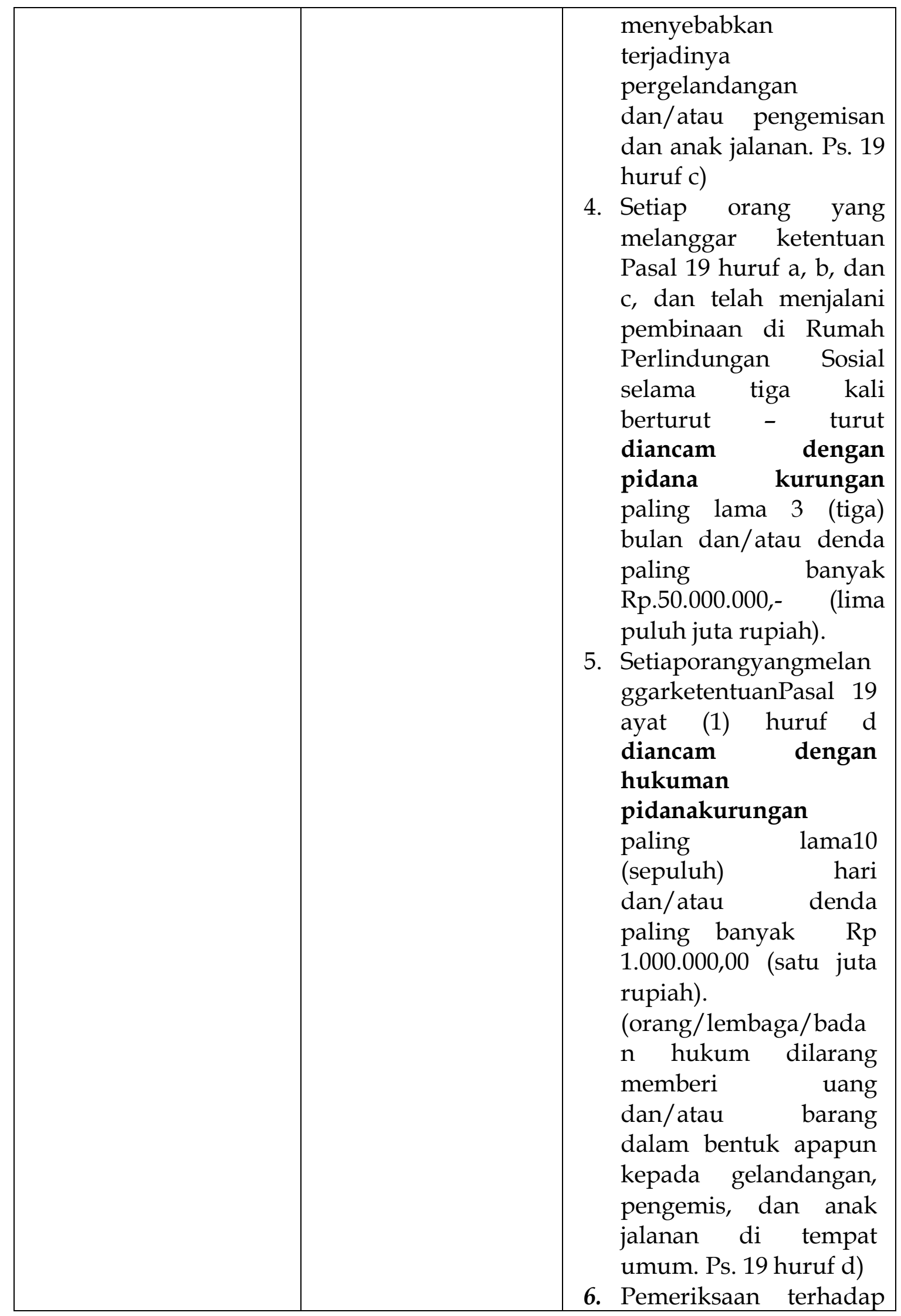




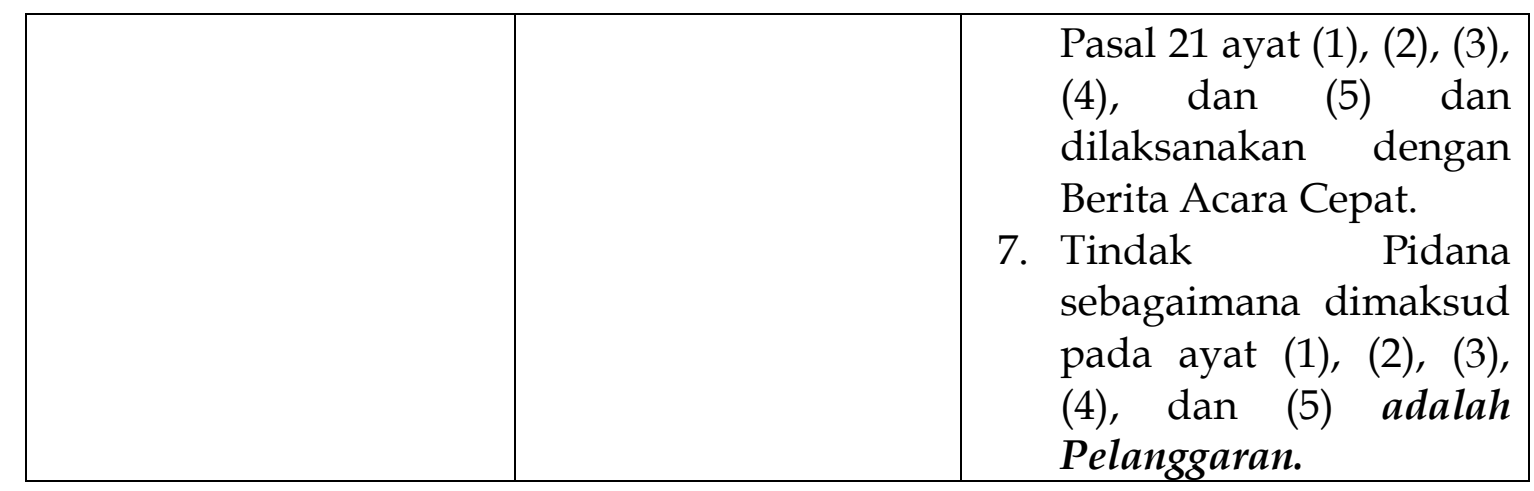

Berdasarkan uraian di atas, maka dapat dikatakan bahwa Perda Penanggulangan Pengemis, Gelandangan, dan Anak Jalanan memiliki kesamaan visi dengan salah satu tujuan negara yang terumus dalam pembukaan UUD NRI Tahun 1945, yaitu meningkatkan kesjeahteraan umum. Adanya kesamaan ini mengindikasikan bahwa sinkronisasi hukum vertikal mulai dari tujuan hingga ke produk hukum tingkat daerah (Perda Penanggulangan Gelandangan, Pengemis,dan Anak Jalanan) berjalan dengan baik, meskipun terdapat beberapa permasalahan dalam hal kebijakan kriminal (politik hukum apa yang dipilih oleh legal drafter).

1) Menurut Peter Mahmud Marzuki, terkait sinkronisasi peraturan perundang-undangan terdapat asas lex superiori derogat legi inferiori yang menjelaskan bahwa apabila terjadi pertentangan antara peraturan perundang-undangan yang secara hirarkis lebih rendah dengan yang lebih tinggi, maka peraturan perundang-undangan yang hirarkinya lebih rendah itu harus disisihkan. Maksud dari kegiatan sinkronisasi adalah agar substansi yang diatur dalam produk perundang-undangan tidak tumpang tindih, saling melengkapi (suplementer), saling terkait, dan semakin rendah jenis pengaturannya maka semakin detail dan operasional materi muatannya. Menilik pada tabel tersebut, maka masih terdapat tumpang tindih aturan antara peraturan yang lebih tinggi ke peraturan yang lebih rendah terkait pemaknaan pengemisan berikut penegakan hukumnya. Sehingga, penerapan asas lex superiori derogat legi inferiori belum terwujud.

2) Pemaknaan ganda pada pengemisan tersebut berdampak pada produk hukum yang dibuat untuk menanganinya. Ketika pengemisan dianggap sebagai penyakit masyarakat yang meresahkan dan mengganggu ketertiban, maka jalur penal atau pidana menjadi opsi terbaik untuk dapat mengatasinya. Sementara, jika pengemisan dipandang sebagai dampak dari kemiskinan, maka solusi untuk menangani pengemisan adalah melalui sarana non penal yang mengedepankan jalur diluar hukum pidana untuk menyelesaikannya. 
Jalur tersebut bisa berupa langkah preventif (pencegahan) pengemisan, maupun solusi represif selain pidana.

3) Kebijakan kriminal yang berubah ubah. Adanya perubahan pada produk hukum, menimbulkan kebingungan pada pelaksanaan dilapangan, selain merusak sinkronisassi hukum yang coba diciptaka melalui produk-produk hukum tambahan yang bersifat teknis dan operasional hingga pada tingkat daerah (perda). Dengan demikian, tujuan negara pun menjadi kabur sebab instrumen pendukungnya justru inkonsisten dengan goals yang hendak dicapai.

\section{SIMPULAN}

Pemaknaan pengemisan di Indonesia, di dalam Peraturan Perundang-Undangan kerap kali terbentur pada sudut pandang pengemisan tersebut dilihat.Definisi pengemisan yang pertama dilihat dari sudut pandang hukum yakni pengemisan dipandang sebagai pelanggaran terhadap ketertiban umum. Sedangkan dalam kacamata sosiologi, pengemisan dilihat sebagai dampak dari kemiskinan dan dikategorikan sebagai penyakit sosial. Adanya dua pengertian yang bertolak belakang ini berdampak pada produk hukum yang terkait seperti KUHP, Undang-Undang Kesejahteraan Sosial, dan Undang-Undang HAM.

Hasil sinkronisasi vertikal menunjukkan bahwa Perda Kabupaten Kudus tentang Penanggulangan Gelandangan, Pengemis, dan Anak Jalanan memiliki kesamaan tujuan dengan tujuan negara yaitu memajukan kesejahteraan umum. Namun demikian, masih terdapat kendala dalam menyinkronkan sepenuhnya utamanya dalam hal kebijakan kriminal. Adapun kendala tersebut masih disebabkan oleh dua definisi yang berbeda dalam memandang pengemisan. Hal ini berdampak pada produk hukum yang terkesan inkonsisten dalam mencoba memutus simpul pengemisan. Diperlukan kesamaan sudut pandang atau perspektif bagi legislator terhadap tindak pengemisan. Hal ini mutlak diperlukan agar tercipta produk hukum yang saling terkait, saling melengkapi, tidak tumpang tindih, dan dapat berjalan di masyarakat untuk menangani tindak pengemisan. 


\section{DAFTAR PUSTAKA}

Direktorat Pelayanan dan Rehabilitasi Sosial Tuna Sosial, "Standar Pelayanan Minimal Pelayanan dan Rehabilitasi Sosial Gelandangan dan Pengemis. Jakarta : Departemen Sosial RI. 2005.

Dun, Willian N. Pengantar Analisis Kebijakan Publik Edisi Kedua. Yogyakarta: Gajah Mada University Press, 2000.

Friedmen, Lawrence Meir. Sistem Hukum Perspektif Ilmu Sosial, Bandung: Nusa Media, 2009.

Hamzah, Andi. Asas-Asas Hukum Pidana. Jakarta: Rineka Cipta, 2010.

Irawan, Dimas Dwi, Pengemis Undercover Rahasia Seputar Kehidupan Pengemis. Jakarta: Titik Media Publiher, 2013.

Islamy, M. IRFAN. Prinsip-Prinsip Perumusan Kebijakan Pemerintah. Jakarta: Bumi Aksara, 2001.

Naskah Akademik Rancangan Peraturan Daerah Kabupaten Kudus tentang Pengemis, Gelandangan, dan Orang Terlantar; Baperenda Kabupaten Kudus Tahun 2016.

Marzuki, Peter Mahmud. Penelitian Hukum, Jakarta: Kencana, 2006.

Soendoro, Emir. Jaminam Sosial Solusi Bangsa Indonesia Berdikari, Jakarta: Dinov Progress Indonesia, 2009.

Subarsono, AG. Analisis Kebijakan Publik: Konsep, Teori dan Aplikasi. Yogyakarta: Pustaka Pelajar, 2011.

Solikin, Abdul Wahab. Analisis Kebijaksanaan Dari Formulasi Ke Implementasi Kebijaksanaan Negara, Edisi Kedua. Jakarta: Bumi Aksara, 2008.

Soekanto, Soerjono. Pokok-Pokok Sosiologi Hukum. Jakarta: Rajawali Press, 2006.

Sedana, gede. Faktor terjadinya gelandangan dan pengemis, https:/ / gedesedana.wordpress.com/2009/07/28/faktorpenyebab -terjadinya-gelandangan-dan-pengemis/, pada tanggal 27 Juli 2019.

Undang-Undang Dasar Negara Republik Indonesia Tahun 1945

Peraturan Daerah Kabupaten Kudus Nomor 15 Tahun 2017 tentang Penganggulangan Gelandangan, Pengemis,dan Anak Jalanan

Peraturan Daerah Kabupaten Kudus Nomer 10 Tahun 1996 jo Peraturan Daerah Kabupaten Kudus Nomor 8 Tahun 2015 tentang tentang Kebersihan, Ketertiban, dan Keindahan (K3) 